\title{
Theory, Practice and Competences in the Study of Pedagogy - Views of Ljubljana and Belgrade University Teachers
}

Klara Skubic Ermenc ${ }^{* 1}$, NATAŠa Živković Vujisić ${ }^{2}$, AND

Vera SPASENOVić ${ }^{3}$

$\approx$ Over the previous decade, higher education in Slovenia and Serbia has undergone considerable reforms, influenced by the Bologna process and its agenda of competence and learning outcomes. In the context of these reforms, the aim of this research is to consider the question of the relationship between the theoretical and the practical education of pedagogues at the university level. Eleven university professors from departments of pedagogy and andragogy at the universities of Ljubljana and Belgrade were interviewed. The semi-structured interviews focused on two main research questions: 1) how they understand the relationship between pedagogical theory and practice, and the identity of pedagogy as a science in that context, and 2) their opinion about the competence-based approach in the context of the study of pedagogy. The findings show that the majority of the interviewed university teachers hold an opinion that pedagogy is primarily a theoretical (reflective) science and, accordingly, that the mastery of theory is crucial for the development of pedagogues' competences. Furthermore, most of them are rather reserved and critical of the competence approach as well as of the practical skills development. Although there are some differences in opinions between the professors from Ljubljana and Belgrade, this study shows that similar discourses prevail. The gap between pedagogical theory and practice is one of the major issues that have been current in pedagogical science in the recent decades. The findings of our research indicate that there is dissatisfaction with the relationship between modern pedagogical theory and practice, accompanied by the need for its reconceptualization.

Keywords: pedagogy, pedagogical practice, competences, university, education of pedagogues, university teachers

$1 \quad{ }^{\star}$ Corresponding Author. University of Ljubljana, Faculty of Arts, Department of Pedagogy and Andragogy; Slovenia; klara.skubic-ermenc@guest.arnes.si

2 University of Belgrade, Faculty of Philosophy, Department of Pedagogy and Andragogy, Serbia

3 University of Belgrade, Faculty of Philosophy, Department of Pedagogy and Andragogy, Serbia 


\section{Teorija, praksa in kompetence $\mathrm{v}$ izobraževanju pedagogov - pogledi ljubljanskih in beograjskih visokošolskih učiteljev}

Klara Skubic Ermenc ${ }^{*}$, Nataša Živković Vujisić in Vera Spasenović

$\propto$ Zaradi vključenosti v bolonjski proces sta Slovenija in Srbija v zadnjem desetletju doživeli obsežne reforme visokega šolstva, vključujoč uvedbo kompetenčnega pristopa in koncepta rezultatov učenja. Raziskava se navezuje na ta kontekst, zato je njen temeljni namen preučitev vprašanja razmerja med teoretičnim in praktičnim izobraževanjem pedagogov na univerzitetni ravni. $\mathrm{V}$ ta namen so avtorice opravile intervjuje $\mathrm{z}$ enajstimi visokošolskimi učitelji, ki poučujejo na oddelkih za pedagogiko in andragogiko na Univerzi v Ljubljani in Univerzi v Beogradu. Delno strukturirani intervjuji so se osredinili na dve temeljni raziskovalni vprašanji: 1) kako profesorji razumejo odnos med pedagoško teorijo in prakso ter $\mathrm{v}$ tem kontekstu tudi identiteto pedagogike kot znanosti; 2) kakšno je njihovo mnenje o kompetenčno zasnovanem študiju pedagogike. Ugotovitve kažejo, da večina intervjuvancev opredeljuje pedagogiko kot prvenstveno teoretično (refleksivno) vedo, zaradi česar obvladovanje teorije razumejo kot ključni element razvoja kompetenc pedagoga. Večina je zadržana in kritična do kompetenčnega pristopa in tudi do razvoja praktičnih spretnosti bodočih pedagogov. Raziskava nakazuje določene razlike $\mathrm{v}$ mnenjih med profesorji iz Ljubljane in Beograda, pa vendarle med vsemi prevladuje podoben diskurz. V zadnjih desetletjih se sicer v pedagoški znanosti kot ena ključnih dilem kaže ravno razkorak med pedagoško teorijo in prakso. Tudi rezultati te raziskave kažejo na določeno mero nezadovoljstva med obstoječim razmerjem in odpirajo vprašanje potrebe po rekonceptualizaciji.

Ključne besede: pedagogika, pedagoška praksa, kompetence, univerza, izobraževanje pedagogov, visokošolski učitelji 


\section{Introduction}

This paper examines the issue of competence-based approaches in the context of the Bologna process by focusing on the study of pedagogy in Slovenia and Serbia. Pedagogy is a science with a lengthy academic tradition (cf. Ermenc, 2015; Ermenc et al. 2013), which was borne out of a twofold interest: 1) research interest in the phenomenon "[...] of the individual's freedom. [Pedagogy sees] education as more than just a process of adaptation and socialisation, but rather as a process of emancipation" (Biesta, 2014, p. 71); 2) Pedagogy was also borne out of practical interest as it responds to the needs of pedagogical professions (teachers, school counsellors, school administrators, etc.) (Ermenc, 2015, p. 43). The dual nature of the pedagogical science has produced many tensions (Vujisić-Živković, 2008), some at the methodological and epistemological levels, and some at the level of the conceptualization of teacher and pedagogue education. Moreover, the study of pedagogy is particularly interesting to investigate on the territory of the former Yugoslavia, as it was there that the study underwent specific development since the late 1950s when the pedagogy graduates, called "pedagogues", began to be employed as regular members of the school staff. Their primary role has until today been to encourage students' personal and academic development and to contribute to the improvement of the educational process in school settings (Ermenc et al., 2013).

Throughout the history of pedagogy, the twofold nature of the science has raised questions on the relationship between pedagogical theory and practice, and produced different conceptualizations of the identity of pedagogy as a scientific discipline. Currently, these debates are linked to the issue of competence-based approach in curriculum design and pedagogical practice. A question arises whether competence-based approach opens up new possibilities for bridging the gap between the theoretical and the practical education of prospective pedagogues. In the first part of the paper, these questions are historically and theoretically discussed; in the second part, the results of a comparative empirical study are presented and discussed.

\section{Historical reflection on the problem of relationship be- tween pedagogical theory and practice}

Examining the historical dimension of the relationship between theory and practice in pedagogy is a common topic in foreign pedagogical literature (Carr \& Kemmis, 2000; Lenzen 2002). Authors often begin by considering Aristotle's definitions of the terms techne, poiesis, and phronesis. Understanding 
a person's actions as craftsmanship (techne) or as practical (moral) reasoning (phronesis) crucially determines Aristotle's answer to the question of how to bridge the gap between pedagogical theory and practice. To explain the origin of the currently generally accepted attitude that practice sovereignly rises above theoretical competence, Gadamer (200o) informs us how the terms theory and practice changed their meanings through history and how the return to Aristotle's viewpoint can aid in understanding these terms in a way that goes beyond the modern binary theory-practice opposition. For Aristotle, theory (theoria) denoted a person's ability of "pure observation of the world" - this "observation" did not mean "[...] ascertaining a state of affairs without taking part in or observing a sumptuous scene, but actual participation in the event, actual presence" (Gadamer, 2000, p. 19). Furthermore, the original concept of practice (praxis) was differently structured: "Practice is characterised by the ability of the human attitude that we call theoretical [...], the ability of theoretical behaviour itself falls under practice" (Gadamer, 2000, p. 156).

Aristotle's answer is particularly useful to pedagogues, and to the issue of the relationship between theory and practice. He does not put theory in opposition to practice as we often do today, but he observes theory in contrast to art and distinguishes four forms of human activity: techne - craftsmanship/ skill, poiesis - art/creation, phronesis - reasoning or proper decision-making and reflection - thinking focussed on learning the truth (Gadamer, 1999, p. 80). Furthermore, according to Aristotle, there are three types of sciences: theoretical (mathematics, metaphysics), practical (politics) and productive (art). Theoretical sciences are based on reflection, practical sciences on phronesis (moral reasoning), while arts on poiesis (creation). Moreover, techne is craftsmanship (not practice) but implies the application of a proper sequence of actions and procedures in making objects. Aristotle would have told us that modern pedagogy has changed the meaning of the word "practice", which it has defined as techne and that this is the reason that the idea of the possibility of a linear transfer from theory into practice has occurred. According to Aristotle, practical sciences are close to practice and are inseparable from it, but it is practice that is different from techne, primarily because it raises the question of the good, of the best way of life and, therefore, requires phronesis (Gadamer, 2000, p. 54). Aristotle would have certainly placed pedagogy among practical sciences that focus on the issue of proper and ethical decision-making (phronesis).

From the perspective of the history of pedagogy in Slovenia and Serbia, the question of the relationship between theory and practice was shaped in the first half of the $19^{\text {th }}$ century by the phrase "pedagogical tact", which referred to the formative aspect of teaching: in the terms of a dominantly patriarchal 
upbringing, in which rewards and punishments were the main educational resources and in which students were expected to respect their teacher unconditionally; the teacher's pedagogy required from teachers to have the "pedagogical tact", in terms of a more liberal attitude to students and a focus on personality and individuality of each child. In the final decades of the $19^{\text {th }}$ century, pedagogy was established as an autonomous scientific discipline, relying mostly on the pedagogical system of Johann Friedrich Herbart (1776-1841) and his successors (Vujisić-Živković, 2012, 2014). Herbart and Herbartians contributed to changing the meaning of the "pedagogical tact"; it occurred as the answer to the question of how to apply deductively derived pedagogical norms into educational practice. Thus, "pedagogical tact" became the central concept through which the researchers attempted to base pedagogical activities on scientific knowledge. The concept was differently interpreted by individual pedagogues (Protner, 2014). For example, Serbian pedagogue Vojislav Bakić (1847-1929) (1873, pp. 166-167) believed that both theory and practice participate in forming the pedagogical tact: education belongs completely to the practical sphere, but the ideas guiding education are not directly given in experience but are the result of critical thinking, generalization and reflection; pedagogical principles and specific educational situations are merged into "pedagogical tact", determining the teacher's course of actions; "pedagogical tact" is a psychological, intellectual, reflective phenomenon, which implies a possibility to be developed through practical actions. Bakićs understanding is close to Aristotle's viewpoint.

In Slovenia, the concept of "pedagogical tact" was later studied by Stanko Gogala (1901-1987). He was a central figure of cultural pedagogy, the successor to Geisteswissenschaft (humanistic) pedagogy, which prevailed in the Slovenian pedagogy after the decline of Herbartism. Gogala (2005) understood "pedagogical tact" as an innate ability, a pedagogue's core quality. In his opinion, a teacher is more an artist than a scientist who uses her intuition to guide students. Gogala nevertheless claimed that a pedagogue is also required to master the theory. The theory helps to stir this innate ability, and - being culturally valuable - also helps her become a warm and open person. Moreover, theory helps a pedagogue to understand her actions and to reflect on them. Knowing the theory also prevents a pedagogue from over-generalizing her experience, and to perceive her single actions as a reflection of general pedagogical principles (Kroflič, 200o; Peček Čuk \& Lesar, 2009). Gogala’s ideas are close to the Aristotle's concept of phronesis: a teacher as an enlightened individual is able to identify formative elements in the teaching content and to autonomously select the most appropriate method that will help students to become autonomous individuals. If the method is prescribed, teaching activity is reduced to techne, 
and teacher's and student's autonomy limited (Medveš, 2000, p. 89). Therefore, the teacher, claims Gogala, has to develop her "own method", a method that is based on the knowledge of didactics, but that nevertheless evolves out of the teacher's personal essence (Ermenc, 2000, p. 150).

\section{Identity and status of pedagogy as a science and the gap between pedagogical theory and practice}

Historians of pedagogy see J. F. Herbart as most deserving for constituting pedagogy as an autonomous scientific discipline, but simultaneously with the implicitly present criticism that he contributed to deepening the dichotomy between theoretical and practical pedagogy as he emphasized the superiority of deductively derived pedagogical norms over pedagogical experience. Herbart divided pedagogy into the theoretical (general) realm, which relies on philosophy and which, as a deductive science, determines the objectives and principles of education, and the practical realm, which is based on psychology and which is inductive and experiential. In an effort to constitute a science of education and to provide it with theoretical dignity and an autonomous status in relation to philosophy and psychology, Herbart partly suspended its praxeological objectives. Herbart's original viewpoints, in the interpretation of Serbian and Slovenian pedagogical science of the final decades of the $19^{\text {th }}$ century, were given a different meaning: pedagogical teleology, dealing with aims and tasks of education and the principles of pedagogical work derived from them became synonymous with pedagogy as a science (Bodroški, 2009; Vujisić-Živković, 2012).

In the interwar period in Serbia, the division into theoretical and practical pedagogy, which at the time was increasingly directed not so much to the methodology of pedagogical work as to the methodology of teaching, remained. In this period, the debate on the relationship of these two "parts" of pedagogy was intensified: a number of pedagogues advocated for the term pedagogy to be used for the "skill of upbringing and educating", as well as that the term pedagogics is more appropriate for the science on education (Mladenović, 1936). This etymological dilemma referred to the question of the relationship between pedagogical theory and practice.

Slovenian pedagogues often advocated pedagogy as a reflective science and have even demonstrated an aversion towards applied pedagogy. When the first pedagogy chair was opened at the University of Ljubljana in 1927, pedagogical practice and theory were established as two separate areas (Medveš, 2010a, p. 92). Pedagogy graduates of the time mainly found employment at teacher training schools, where they taught pedagogical and psychological 
theory to future primary school teachers and the methods of instruction of all of the primary school subjects. The teachers graduating from these schools had been well trained in teaching methods, because the teacher trainers did not base their pedagogical process solely on the academic pedagogy, but also on teacher pedagogy, which had been developing since the mid-18oos within the framework of teachers' associations (Medveš, 2010b, pp. 88-89).

With the development of experimental pedagogy and psychology in the interwar period, the issue of the "usefulness" of pedagogical science, whose dominant stood fast in philosophy, was strongly raised. From the science, which was perceived in the $19^{\text {th }}$ century as the most significant for teachers' education to which today dominantly applies the value judgement that its development on the national level had a key role in modernizing the school system and improving the quality of teaching, pedagogy has been faced with criticism that without knowledge gained by experimental methods it does not have a reliable basis for pedagogical practice. The renaissance of the neo-positivist approach that we are witnessing today and often take part in, the evidence-based approach that has directed pedagogical research towards quantitative methodology with the aim of detecting casual relations by a randomized experiment on large random samples and to prove reliably "what works" in education (Slavin, 2002, 2008), has re-actualized the old issue of the relationship between pedagogical theory and practice. The educational policy, along with the scientific and research policy in the field of education related to it, which so positively evaluate the applied research, equally contributed to this, while fundamental research is seen as needed per se, but there is less interest in it. Pedagogy has been faced with the requirement to provide an answer to the question "how", i.e. in what way, to increase education quality by using ICT, and how to make each student achieve knowledge standards via the individualization of teaching. Although these questions are legitimate in scientific terms, when queried by the education policy, pedagogical research is not expected to critically consider the question "why", i.e. a socio-historical, economic, political context, within which certain innovation ("how") can be successful, while the habitus of the researcher is recognized by the need to understand, explain and try to answer the question "why". Trapped by increasingly louder demands coming from the education policy sphere to provide an answer through its research to the question of "what works" in education, the pedagogical research community has been facing the danger of neglecting its analytical and critical function, which it had the time of being created as an autonomous scientific discipline in the $19^{\text {th }}$ century, although at that time it was accused of being "a maidservant to philosophy", and by analogy it may become today "a maidservant" to the education policy. 
The analysis of pedagogical science development in Switzerland carried out by Hofstetter and Schneuwly (2001, 2002) indicated that the contradictory relationship between the requirements that come from the professional field and from the scientific field, the tension between the guild and professional needs on one hand, and the search for scientific affirmation on the other, placed pedagogy into the space between pragmatic and scientific imperatives. The need for pedagogy to distance itself from practice in order to attain the knowledge that exceeds praxeological objectives has led to the suspension of the praxeological dimension.

Today, perhaps as never before, pedagogy has been faced with practitioners' criticism that pedagogical research is irrelevant for their everyday work that it is unclearly written, that instead of clarifying the issues it opens up new dilemmas. At the same time, the tension between theory and practice has been followed by blind faith that learning from experience occurs automatically and by aversion to the systematic analysis and research into practical work (Keiner, 2002; Rusell, 1993). How can the trends described be explained? Gadamer (2000) estimates that the final decades of the $20^{\text {th }}$ century were characterized by the victory of practice over "purely theoretical competence" in the field of all social sciences and humanities, i.e. that scientific and theoretical knowledge "lost its former dignity, while suspicion to theoretical knowledge of those lacking experience was enthroned [...], an antidogmatic tone in the word practice took a victory over purely theoretical competence" (Gadamer, 2000, p. 33).

Modern philosophy indicates that the key issue is that today we are accustomed to seeing practice as the application of theory (Gadamer, 1999, p. 28). In this context, it is important to emphasize that education is not understood as behaviour (techne), but as doing (praxis). Social sciences have praxis as their subject. Gadamer (20oo, pp. 124-146) emphasized that practice is not the application of science; rather, practice is the source of experience and knowledge. Therefore, the ability that we need in practical activity is not the ability to apply science, but the ability to choose and make right decisions; we ask the question about the good (phronesis), and our ideal is not to exclude all that is subjective from rational examination, since in practice we always personally decide and choose.

Thus, in pedagogy we have to go back to the most difficult and the oldest question, since only with understanding the relationship between a pedagogical opinion and an activity can we find what Jan Bengstsson (2006) called "the self of pedagogical science", i.e. its autonomous identity that would enable a productive dialogue between practitioners and researchers. Pedagogy has a task to provide a synthetic framework and unity of the discipline, to "canonize" 
a methodological approach that would take into account scientific, ethical and socio-political objectives and scientific disciplines and educational practice.

\section{Competence-based approach in the context of the study of pedagogy}

The concept of the competence-based approach in curriculum design and pedagogical practice has been a topic of numerous studies and heated debates in the previous decade (Laval, 2005; Štefanc, 2006). In the pedagogical field, the issue has been often related to the question of teachers' competences and teacher professional development; also in Slovenia and Serbia (Cvetek, 2004; Korać, 2012; Marinković \& Kundačina, 2012; Muršak, Javrh, \& Kalin, 2011; Peklaj, 2006; Peklaj et al., 2009; Plevnik, 2005; Razdevšek Pučko, 2004; Stojanović, 2008; Vranješević \&Vujisić-Živković, 2013). Many researchers support the idea that modern teacher education and teacher professional development need to be based on competences, not only because competence-based approaches focus on the goal of teaching future teachers how to "do things in practice" (Razdevšek Pučko, 2004, p. 71), but also because contemporary teachers need to be able to constantly adapt to changing circumstances (Buchberger, Campos, Kallos, \& Stephenson, 2000; Peklaj et al., 2009, p. 9). The competencebased approach fits well within the European life-long learning agenda, including the Bologna process. Thus, supported by European financial mechanisms, many projects have been set up to apply and evaluate the concept of competence in teacher education. Many of them have produced lists of teachers' competences, which are supposed to serve as the basis for teacher education (Peklaj, 2009; Pravilnik o standardima kompetencija ..., 2011; Vizek-Vidović \& Velkovski, 2013; Šteh, Kalin, \& Mažgon, 2014).

"A competence is defined as the ability to successfully meet complex demands in a particular context through the mobilization of psychosocial prerequisites" opens the famous DeSeCo definition of competence (Rychen \& Salganik, 2003, p. 43, the authors' emphases), and continues: “The primary focus is on the results the individual achieves through an action, choice, or way of behaving, with respect to the demands, for instance, related to a particular professional position [...]" (Rychen \& Salganik, 2003, p. 43, the authors' emphasis). The definition implies that educational programmes (if they are to be competence-based) need to be based on a clear definition of the "professional positions" for which they are designed. This may not be such a difficult task when one has a teacher's profile in mind. The issue becomes much more complex and controversial when the professional profile of a pedagogue is in question. The 
profile of a pedagogue has historically changed considerably, and even today, there is no wider consensus on its nature.

In the past, the study of pedagogy used to be related to teacher education and, since its beginnings, it has also been related to other professional positions in the education system (in administration, inspection, research, etc.). However, in the 1970s, the school counselling service was introduced in the former Yugoslavia; its introduction has had a crucial effect on the study of pedagogy: "Perhaps no profile, neither before nor after, has so decisively influenced the formation of pedagogy study as the very profile of the school pedagogue," argued Medveš (2010b, p. 104). Despite the fact that the profile of school pedagogue influenced the study of pedagogy considerably, there is not much debate about the relationship between the study and the profile. The general impression, based on the comparison of study programmes (Spasenović \& Ermenc, 2014), is that (at least at the Belgrade and Ljubljana universities) an equation between the study and the profile cannot be made. Both study programmes, in Belgrade and in Ljubljana, are conceptualized in much broader manner, giving more focus on the study of science than on the training of future (pre)school pedagogues and other professionals in the educational field. ${ }^{4}$ This position is well reflected in the formulation of general aims of the pedagogical studies. To mention but one aim of the study of pedagogy in Belgrade: "Training for an understanding of education in the light of the early ideas of classical and modern pedagogical theories and concepts" (Spasenović \& Ermenc, 2014, p. 28). As far as the training of practitioners is concerned, it seems that the profile of (pre)school pedagogue has remained the central focus of the programmes, but that also other professional positions have been taken into consideration (reflected in competences related to work in administration, leadership and research). Since the study was limited to the analysis and the comparison of organization and structure of the programmes, their general goals, and the types of educational activities, these conclusions are less reliable, which is why we have studied them further.

\section{Method}

The aim of the empirical research was to examine the opinions of university teachers at the Departments of Pedagogy and Andragogy at Ljubljana and

4 Recently, a survey on employment situations was conducted by the Department of Pedagogy and Andragogy in Ljubljana (Radovan, Mažgon, \& Ermenc, 2014). The data shows that only 42.2 percent of alumni who graduated between 2010 and the first half of 2014 have found employment in schools or kindergartens. This finding speaks in favour of the existing conceptualization of pedagogy studies; limiting the study of pedagogy to the school pedagogue profile (and thus making it more competence-based) would negatively affect the employability of the graduates. 
Belgrade universities on the competence-based approach that was introduced by the Bologna process. Given that the introduction of this approach is closely connected to the issue of the relationship between pedagogical theory and practice and the issue the identity of pedagogy as a science, we set the following research topics: 1) consider how teachers understand the relationship between pedagogical theory and practice and the identity of pedagogy as a science in that context; 2) examine how, from the perspective of the relationship between pedagogical theory and practice, teachers assess the study programme of pedagogy; and 3) examine their attitude towards competence-based pedagogy study programmes.

We have conducted a qualitative comparative study, and chosen the technique of research interview (Kvale \& Brinkmann, 2015). The sample includes eleven teachers, six from the Department of Pedagogy and Andragogy at the University of Ljubljana (they teach the following courses: History of Education, Theory of Education, Sociology of Education, Didactics (two professors), Vocational Pedagogy), ${ }^{5}$ and five from the Department of Pedagogy at the University of Belgrade (they teach History of Education, General Pedagogy, Didactics (2 professors), Preschool Education). We have selected interviewees based on three criteria: they all have at least ten years of experience working as a university teacher in the field of pedagogy; they teach one of the fundamental pedagogical courses, and have taken part in academic discussions (oral or written) on the issues about the nature and identity of pedagogy.

Semi-structured questionnaires were used. In order to determine the categories for the analysis of university teachers' answers, we have used an inductive approach to develop categories based on an analysis of original data (Cohen, Manion, \& Morrison, 2007; Lodico, Spaulding, \& Voegtle, 2006). Because of the similarities in the historical development of the pedagogical studies in both countries, we have primarily paid attention to the individual respondents' views, and focused on their comparison regardless of the university at which they work. As shown below, the study shows that similar discourses prevail and that opinions within them differ. There are however some differences between the two environments as well.

\section{Results}

\section{The identity of pedagogy}

We can speak of three conceptualizations of pedagogy as a science. Pedagogy can be understood as 1) primarily a reflective (theoretical) science, as 2)

5 We have marked respondents form Ljubljana as RL (RL1 to RL6), and respondents from Belgrade as $\mathrm{RB}\left(\mathrm{RB} 1-\mathrm{RB}_{5}\right)$. 
primarily an applied science, or 3) as both a reflective and applied science. All but two respondents agreed that theory plays a crucial role. Their views were usually expressed in the context of the nature of pedagogy study programmes: "The study has to begin with the theory, so that the students gain the fundamental knowledge. [...] the theory equips them with meta-knowledge and [...] which enables transfer to different practical situations" (RL6); "It is wrong to assume that the programmes have too much theory. I think it is just the opposite, that they [the students] do not master the theory well enough" (RL4); "The theory develops the tools that enable critical evaluation of practice." (RB5)

All respondents in Ljubljana and three in Belgrade agreed that the mastery of the theory is crucial for the development of pedagogues' competences. Theory enables professionals to solve a multitude of professional problems, to function effectively in diverse professional situations and occupational positions. That is why the main task of the professors is to help students to "[...] develop cognitive apparatus" (RL1); "Being qualified for the occupation implies the mastery of theoretical knowledge. But, knowledge has to be well assimilated and interiorized in order to construct an argumentative network, which enables finding answers to practical dilemmas and the reflection of one's own actions in practical situations." (RL4)

Moreover, not just the mastery of theory, but also the mastery of the research methodology is what is required to meet the above-stated goals. Such a view has been directly emphasized by seven respondents ( $R L_{1}, R_{2}, R_{3}, R_{4}$, $\left.R B_{1}, R_{2}, R_{3}\right)$. RL2 said: "My goal is to teach students to be able to identify didactical issues in pedagogical practice. In my opinion this is a research activity. [...] I aim to teach the students to be able to identify a problem, to prepare a research plan, design the instruments, write the report and evaluate the findings critically."

The respondents expressed varied views on the relationship between theory and practice. Our analysis reveals that the majority of respondents (7) share their opinion with the prevailing pedagogical tradition and understand pedagogy primarily as a reflective science. Two of them see it as both, reflective and applied science and two as primarily an applied science.

The two respondents who see pedagogy as both a reflective and applied science explain their views on the relationship between theory and practice as follows. RL2 continuously emphasized the importance of theoretical study and solid mastery of research skills, but she nevertheless sees the drawback of the pedagogy programmes as being that they do not include the training of students for some important professional skills, such as conducting dialogue in a counselling setting. 
RL3 defends the position that pedagogy is "both a reflective and applied science [...]. Pedagogy is about action. It is a discipline that has to develop conceptual tools for the analysis of the pedagogical reality. It also needs to be able to develop new approaches at the micro-pedagogical as well as at the systemic level." The respondent goes on explaining that analysis is not enough (this is something other social sciences do when analysing pedagogical phenomena), but has to (according to the Geisteswissenschaft pedagogy) develop clear normative answers to the questions related to education in given time and space. "We pedagogues think about practical solutions to pedagogical questions." (RL3)

Lastly, one (RB2) of the two respondents who see pedagogy as primarily an applied science, claims that "Practice should be the cause for theory, the source of theoretical problems and motive for the questioning of the theory, only later for the proof of the theory."

\section{The role of the pedagogical practicum within study programmes}

Most respondents agree with the idea that the theory is the best teacher of practice, but they interpret it differently. To begin with, all respondents agree that giving the students the opportunity to be engaged in the educational institutions' activities for a certain period is important and valuable. Three respondents (RL4, RL1, RL6) simultaneously warn of the potential negative effect of a practicum: practical engagement can, if not supported by reflection, enhances dogmatic instead of reflective thinking.

The respondents value the pedagogical practicum as a very useful tool that can increase the students' motivation for studying (RL1, RL2, RL5, RL6), and as a tool that can help them understand the theory better (RL1, RL2, RL4, $\mathrm{RL6}, \mathrm{RB1}$ ): "Students have the opportunity to see how theory is useful in practice $[\ldots]$ how different theories are applied to different pedagogical situations" (RL2). Such responses show that the prevailing stance among the university professors is that pedagogy in a reflective science, where practical experience supports theoretical study. In their view, practice is certainly not about techne, but it is about supporting the development of the students' reflectivity and motivation for studying.

The respondents who understand pedagogy in the interspace between theory and practice $\left(\mathrm{RL}_{2}, \mathrm{RL}_{3}, \mathrm{RB}_{4}\right)$, see the pedagogical practicum as having more profound impact. One respondent (RB4) explains: "Taking part in the pedagogical practicum gives the students the opportunity to investigate authentic situations, to reflect on them, and to select, rearrange and integrate knowledge [and by doing this] to construct their own system of knowledge, abilities and attitudes." 
Respondent RL2 understands pedagogical practicum as one element of the students' phronesis development. He has established a holistic didactic strategy that builds on the students' experience. He explains: "Drawing on Herbart and Dewey, I believe that learning occurs in the combination of theory and practical engagement. [...] Practice is not a direct experience; it becomes as such when linked to theory. Theory is the instrument that helps them [the students] gain experience." Students in one of his courses are required to observe some pedagogical phenomena at schools. Before conducting the observation, they participate at lectures to gain theoretical knowledge on the phenomena. When the observation is over, they write papers discussing their observations and evaluating them theoretically. Students receive thorough feedback and are required to make corrections. Later, the students and two professors meet for a weekend seminar where the same issues are discussed from several theoretical viewpoints over the course of three days.

\section{The professional profile of a pedagogue and the views on the concept of competence}

The characteristics that stand out the most are: pedagogues should be ethical, intellectual, critical professionals ( $\left.\mathrm{RL}_{1}, \mathrm{RB}_{5}, \mathrm{RB}_{4}\right)$; they should have good methodological skills ( $R L_{1}, \mathrm{RL}_{2}, \mathrm{RL}_{3}, \mathrm{RL}_{4}, \mathrm{RB}_{3}$ ), and be able to read fundamental texts, defend their professional opinion and keep critical distance ( $\mathrm{RL}_{2}, \mathrm{RB} 5, \mathrm{RB}_{4}, \mathrm{RB}_{3}$ ). They should be able to function effectively in different occupational positions and situations, and reflect on their decisions and actions, on the decisions of others ( $\mathrm{RL}_{1}, \mathrm{RL}_{2}, \mathrm{RL}_{3}, \mathrm{RL}_{4}, \mathrm{RB}_{4}$ ). The following characteristics are mentioned less often: good communication and social skills $\left(\mathrm{RB}_{5}, \mathrm{RB}_{4}, \mathrm{RB}_{2}, \mathrm{RB}_{3}\right)$, the ability to work in teams $\left(\mathrm{RB}_{2}, \mathrm{RB}_{3}\right)$, and "pedagogical tact” (RB3).

Such a profile does not go well with the mainstream competence discourse: all respondents in Ljubljana and three in Belgrade are rather critical about it. More than to the concept itself, the critique is directed towards the global higher education policy, which is attempting to reduce the cost of higher education in a dangerous way $\left(\mathrm{RL}_{3}\right)$, and therefore promotes a narrow behaviouristic concept of competence. Nonetheless, many agree (RL2, RL3, RL4, RL5, $\mathrm{RB}_{1}, \mathrm{RB}_{2}, \mathrm{RB}_{5}$ ) that the competences can be defined so as to be pedagogically valuable: "I draw on the concept of competence but in a way I find it appropriate for the study of pedagogy; I understand it as an integration of knowledge, action, and reflection. By 'action' I understand mostly methodological skills” (RL2).

Similarly, the respondent $\mathrm{RB} 2$ understands as the "... integration of academic knowledge, skills, and attitudes [...]. To avoid being overly academic, 
however, I would not want to transform the pedagogue's profile into a technical one."

Respondent RL3 explains that the concept of competence could be explained in the sense of phronesis, but phronesis requires a thorough theoretical study, which policy does not support. "You simply cannot comprehend a professional problem without leaning on theory. The issue is not either to choose a discipline-based curriculum model or a practically-based competence model; it is about the integration of the two. Dewey's statement that theorizing is lame and practicing is blind is still valid" ( $\left.\mathrm{RL}_{3}\right)$.

Even the respondent who expressed one of the most critical attitudes about the competence concept (RL4), says that she finds MacBeath's conceptualization useful: "Students should reach learning aims at three levels: at the levels of knowing, feeling and acting; [...] each level encompasses the dimensions of understanding, abilities (or competences) and values" (RL4).

When confronted with the issue of the professional profile of pedagogues and their competence development, all respondents in Ljubljana and three in Belgrade agreed that focusing on the occupational position of a (pre)school pedagogue/counsellor would require a highly problematic narrowing down of the profile. When having occupational challenges in mind, the professors do often focus on the (pre)school pedagogue's occupational tasks and problems, but simultaneously say that the study of pedagogy has always been much more broadly conceptualized, covering topics from the macro-systemic to the micropedagogic levels (RL1, RL5, RL6, RB1, RB4, RB5). Moreover, the graduates have always been able to find employment in very diverse organizations.

\section{Has the Bologna model influenced the respondents' in any way?}

A general answer to the question is negative. Some respondents (RL1, $\mathrm{RL}_{4}, \mathrm{RB}_{3}$ ) even claim that the Bologna process enhanced their negative feelings about the competence concept. RB3 comments: "The Bologna reform [...] has brought about a set of changes which were for me as a teacher more frustrating than inspiring, especially concerning quantitative evaluation of students' and teachers' achievements." In contrast, the process also had positive influences on her as a researcher: "The Bologna process opened for me a new and utterly challenging field of research - higher education. [...] I have realized what traps are hiding in education if the development of education is led by policy platforms based on ministerial conferences, instead of being led by internal theoretical explanations" (RB3).

Despite having a critical stance toward competence-based approach, one respondent $\left(\mathrm{RB}_{4}\right)$ claimed that insistence on competences in Serbia has 
challenged the prevailing encyclopaedism in the study programmes and provided a good opportunity to reflect on the essence of the profession. Moreover, a few respondents from Serbia recognized some positive sides of Bologna process, such as the introduction of new courses $\left(\mathrm{RB}_{2}\right)$, reconsideration of the professional role of pedagogue $(\mathrm{RB} 1)$, and the teachers' roles in preparing prospective pedagogues ( $\left.\mathrm{RB}_{2}, \mathrm{RB}_{5}\right)$.

Respondents RL2 and RL3 explained that they developed their didactic model before the introduction of the Bologna model. When introducing improvements into syllabi and teaching approaches, the professors lean on their expertise and experience, and not on Bologna model directions. The resistance to top-down delegated reform is well described by respondent RB3: "No student-centeredness. Not professor-centeredness. But the academic community in the centre. This implies academic freedom of the professor in the conceptualization of the educational programmes, and the academic freedom of students to study the way they find appropriate." She continues, stating that professors are also researchers, whose work is constantly evaluated in their academic community. Therefore, they are the only ones who can competently decide what to teach. "Nobody from outside cannot know this better than them. That is why the selection of the university teachers is crucial."

\section{Conclusion}

The findings of our research show that the majority of the interviewed university teachers hold an opinion that pedagogy is foremost a theoretical (reflective) science: it is more about theoria and reflection than about phronesis and techne. Some of the respondents share the authors' stance that pedagogy is about both, about theoria and about phronesis: learning the truth and gaining wisdom of ethical decision-making ("pedagogical tact") are more important than merely the craft of coping with everyday teaching practice (Gadamer, 1999 , p. 80). Least pronounced is the stance that pedagogy is primarily a practical science that should equip students with practical professional skills.

The stance that pedagogy is more than anything a theoretical science is more pronounced among the respondents from the University of Ljubljana. Not surprisingly, they also see pedagogical theory as having a crucial role in the education of prospective pedagogues. Theory is, in their opinion, also the basis for students' practical training. In spite of the contemporary societal atmosphere in which applied (i.e. useful) knowledge (techne) is favoured, the mainstream opinion among academic pedagogues still is that "there is nothing more practical than a good theory" (Medveš, 2010a, p. 92). This stance is also 
held by those respondents who see pedagogy as not only reflective but also as an applied science. The difference between the two groups of respondents is the following: the first group understands the students' development of research skills as the main bridge that links theoretical studies and practical training; the second group, however, sees the engagement of students in pedagogical practicum as one of the two fundamental preconditions of the students' phronesis development: professional development can be equated with phronesis development. The second precondition is that the students need to have the opportunity to develop the ability to reflect theoretically on their practical experience.

Not surprisingly, the last group of respondents (coming from Belgrade University), who see pedagogy primarily as an applied science, have relatively positive attitudes about the competence approach. The analysis also reveals that the competence approach is generally much better accepted by Belgrade than by Ljubljana respondents. Compared to the Ljubljana respondents, the Belgrade ones also express a slightly more pronounced need for the practical skills development. The majority of the interviewees are, however, rather reserved and critical to both the competence approach as well as the practical skills development; they fear that competence-approach would lead to its reduction to techne in the given political and societal atmosphere.

Taking that into consideration, it must also be noted that even the harshest critics of the competence concept express the stance that competence approach (if understood holistically) could positively influence the students' ability to use theoretical knowledge and research skills when dealing with complex occupational challenges. If anything, our respondents agree that this is one of the fundamental study aims they strive for, but are only rarely successful at achieving. This is why we believe that it might be useful to further investigate and develop the idea of a competence model, or perhaps, a phronesis model that would be suitable for the professional development of pedagogues. Such a model might respond better to the above-mentioned practitioners' criticism on the practical irrelevance of pedagogical research for their everyday work: if reduced to techne, the competence approach, is not a solution to the problem. The competence-approach if understood holistically, and with the concept of phronesis at the centre, might produce better results. 


\section{References}

Bakić, V. (1873). Pedagogijski takt. Škola, (9), 138-139; (10), 150-153; (11), 166-167; (13), 202-213. Biesta, G. (2014). Is philosophy of education a historical mistake? Connecting philosophy and education differently, Theory and Research in Education, 12(1), 65-76. DOI: 10.1177/1477878513517338 Bodroški, B. (2009). Herbartova koncepcija vaspitanja: značaj i aktuelnost osnovnih postavki. Pedagogija, 64(1), 5-22.

Buchberger, B., Campos, P., Kallos, D., \& Stephenson, J. (Eds.) (200o). Green Paper on Teacher Education inEurope: High Quality Teacher Education for High Quality Education and Training. Thematic Network on Teacher Education in Europe. Umea: Fakultetsnämnden för lärarutbildning, Umea universitet.

Carr, W., \& Kemmis, S. (2000). Becoming critical. London: The Falmer Press.

Cohen, L., Manion, L., \& Morrison, K. (2007). Research Methods in Education. London and New York: Rutledge.

Cvetek, S. (2004). Kompetence v poučevanju in izobraževanju učiteljev. Sodobna pedagogika = Journal of contemporary educational studie, 55(special edition), 144-160.

Ermenc, K. S. (2000). Izobrazba in vzgojno-izobraževalni proces v pedagogiki Stanka Gogale.

Sodobna pedagogika = Journal of contemporary educational studies, 51(5), 142-159.

Ermenc, K. S. (2015). The role of comparative pedagogy in comparative educational research.In A. W. Wiseman \& N. Popov (Eds.), International Perspectives on Education and Society, Vol 26,

Comparative Sciences (pp. 37-57). Emerald Group Publishing Limited.

Gadamer, H. G. (1999). Evropsko nalseđe. Cetinje: Oktoih.

Gadamer, H. G. (200o). Um u doba nauke. Beograd: Plato.

Gogala, S. (2005). Izbrani spisi. Ljubljana: Društvo 2000.

Hofstetter, R., \& Schneuwly, B. (2001). The Educational Sciences in Switzerland: Evlolution and Outlooks. Bern: CSTS.

Hofstetter, R., \& Schneuwly, B. (2002). Institutionalisation of Educational Sciences and the Dynamicsof Their Development. European Educational Research Journal, 1(1), 3-26.

Keiner, E. (2002). Education Between Academic Discipline and Profession in Germany after World

War II. European Educational Research Journal, 1(1), 83-98.

Korać, I. (2012). Kompetencije nastavnika za realizaciju nastavnih sadržaja. Nastava i vaspitanje, 61(1), 99-109.

Kroflič, R. (2000). Avtoriteta in pedagoški eros - temeljna koncepta Gogalove vzgojne teorije.

Sodobna pedagogika = Journal of contemporary educational studies, 51(5), 56-83.

Kvale, S., \& Brinkmann, S. (2015). Inter Views. Learning the Craft of Qualitative Research Interviewing (Third Edition). SAGE Publications, Inc.

Laval, Ch. (2005). Šola ni podjetje: neoliberalni napad na javno šolstvo. Ljubljana: Krtina.

Lenzen, D. (2002). Vodič za studijznanosti o odgoju - štomože, štoželi. Zagreb: Eduka.

Lodico, G. M., Spaulding, D. T., \& Voegtle, K. H. (2006). Method in Educational Research - From 
Theory to Practice. San Francisco: Jossey-Bass.

Marinković, S., \& Kundačina, M. (2012). Razlike u kompetencijama nastavnika razredne nastave stečenim tokom inicijalnog obrazovanja, redovnog i obrazovanja uz rad. Pedagogija, 67(4), 536-545. Medveš, Z. (2000). Legitimnost vzgoje v javni šoli. Sodobna pedagogika = Journal of contemporary educational studies, 51(5), 186-197.

Medveš, Z. (2010a). O kontinuiteti in diskontinuiteti v razvoju pedagogike na Slovenskem. In N. Ličen (Ed.), Kulture $v$ dialogu (pp. 91-104). Ljubljana: Filozofska fakulteta.

Medveš, Z. (2010b). Pedagogika med humanistiko, družboslovjem in tehniko. In D. Nečak (Ed.),

Pogledi (pp. 84-113). Ljubljana: Znanstvena založba Filozofske fakultete.

Mladenović, V. (1936). Opšta pedagogika. Beograd: Izdavačka knjižarnica Gece Kona.

Muršak, J., Javrh, P., \& Kalin, J. (2011). Poklicni razvoj učiteljev. Ljubljana: Znanstvena založba Filozofske fakultete.

Peček Čuk, M., \& Lesar, I. (2009). Moč vzgoje. Ljubljana: Tehničnazaložba Slovenije.

Peklaj, C. (Ed.) (2006). Teorija in praksa v izobraževanju učiteljev. Ljubljana: Center za pedagoško izobraževanje Filozofske fakultete.

Peklaj, C., Kalin, J., Pečjak, S., Puklek Levpušček, M., Valenčič Zuljan, M., \& Ajdišek, N. (2009).

Učiteljske kompetence in doseganje vzgojno-izobraževalnih ciljev v šoli. Ljubljana: Znanstvena založba

Filozofske fakultete.

Plevnik, T. (Ed.) (2005). Pomembneteme v izobraževanju v Evropi: v Sloveniji Prenavljanje pedagoškega študija, v Evropi Učiteljski poklic v Evropi: zbornik besedil o izobraževanju učiteljev.

Ljubljana: Ministrstvo za vzgojo in šport.

Pravilnik o standardima kompetencija za profesiju nastavnika i njihovog profesionalnog razvoja.

Retrieved 1. 11. 2014 from http://www.zuov.gov.rs/novisajt2012/dokumenta/132_standardi-

nastavnika_cir.pdf

Protner, E. (2014). Wege der Durchsetzung des Herbartianismus - am Beispiel Sloweniens. History of Education \& Children's Literature, 9(1), 431-451.

Radovan, M., Mažgon, J., \& Ermenc, K. S. (2014). Employment Status of the Graduates of the Department of Pedagogy and Andragogy. Ljubljana: Department of Pedagogy and Andragogy (unpublished survey).

Razdevšek Pučko, C. (2004). Kakšnega učitelja potrebuje (pričakuje) današnja (in jutrišnja) šola? Sodobna pedagogika = Journal of contemporary educational studies, 55(special edition), 52-74.

Rusell, T. (1993). Teachers professional knowledge and the future of teacher education. Journal of Education for Teaching, 18(2), 205-216.

Rychen, D. S., \& Salganik, L. H. (Eds.) (2003). Key Competencies for a Succesfful and Well-Functioning Society. Seattle, Toronto, Bern, Göttingen: Hogrefe \& Huber.

Slavin, E. R. (2002). Evidence-based Education Policies: Transforming Educational Practice and Research. Educational Researcher, 31(7), 15-28.

Slavin, E. R. (2008). Perspectives on Evidence-Based Research in Education. What Works? Issues in Synthesizing Educational Program Evaluations. Educational Researcher, 37(1), 5-14. 
Spasenović, V., \& Ermenc, K. S. (Eds.) (2014). Kakovost univerzitetnega izobraževanja: mnenja študentov oddelkov za pedagogiko in andragogiko v Beogradu in Ljubljani. Ljubljana: ZnanstvenazaložbaFilozofskefakultete; Beograd: Institut za pedagogiju I andragogiju Filozofskog fakulteta.

Stojanović, A. (2008). Kompetencije nastavnika u svetlu promena u savremenom obrazovanju. Inovacije u nastavi, 21(1), 61-69.

Štefanc, D. (2006). Konceptkompetence v izobraževanju: definicije, pristopi, dileme $=$ The concept of competence in education: definitions, approaches, dilemmas. Sodobna pedagogika = Journal of contemporary educational studies, $57(5), 66-85$ \& 30-44.

Šteh, B., Kalin, J., \& Mažgon, J. (2014). The role and responsibility of teachers and students in university studies: a comparative analysis of the views expressed by pedagogy students. Zbornik Instituta za pedagoška istraživanja, 46(1), 50-67.

Vizek-Vidović, V., \& Velkovksi, Z. (Eds.) (2013). Nastavnička profesija za 21.vek. Beograd: Centar za obrazovne politike.

Vranješević, J., \& Vujisić-Živković, N. (2013). Profesionalni identitet nastavnika i obrazovanje između kompetencija i ideala. Teme, 37(2), 581-594.

Vujisić-Živković, N. (2012). Vojislav Bakić i razvoj pedagoške nauke u Srbiji. Beograd: Instutut za pedagogiju i andragogiju Filozofskog fakulteta u Beogradu.

Vujisić-Živković, N. (2008). Proces disciplinarizacije u polju pedagoškog istraživanja i obrazovanja - prvi deo: Istorijsko-komparativni kontekst razvoja pedagogije kao univerzitetske discipline.

Pedagogija, 63(1), 540-554.

Vujisić-Živković, N., \& Vranješević, J. (2014). Slika učenika osnovne škole u Srbiji u prvoj polovini XIX veka. Nastava i vaspitanje, 63(2), 245-257.

\section{Biographical note}

Klara Skubic Ermenc is Associate Professor at the Department of Educational Sciences, Faculty of Arts, University of Ljubljana, Slovenia. She teaches several undergraduate and graduate courses: Comparative Pedagogy, Educational Systems, European Education Policy, Intercultural Education. Her fields of research are: European trends in education, vocational education and pedagogy; the role and the development of comparative pedagogy, and intercultural education and education of students with immigrant background. She has published around 70 scientific articles, contributing chapters or abstracts, one university textbook, co-authored 2 scientific and 7 professional monographs. 
NATAŠA Vujısıć-Žırvković, PhD, is Full Professor at the University of Belgrade, Faculty of Philosophy, Department of Pedagogy and Andragogy. Her main area of study and research includes: History and Epistemology of Pedagogy, Comparative, Historical and Ethical Aspects of Pedagogical Teacher Education. She has published four books (the last one: Supervision of Primary schools in Serbia in the First Half of the 19th Century, 2014), more than hundred papers in peer review journals and conference proceedings. She has developed international collaboration network with colleagues from many universities.

Vera Spasenović is Associate Professor at The Department of Education, Faculty of Philosophy, University of Belgrade, Serbia. She gained much of her research experience as a researcher at the Institute for Educational Research in Belgrade. She published two monograph, and more than 80 papers, contributing chapters or abstracts. Her current academic interests focuses on comparative analyses of national education systems, comparative perspectives of international education reform, education system in Serbia, and social relationships in school context. She teaches different courses at basic, master and doctoral level, such as: School Education, Comparative Education, Development Directions of Education Systems etc. 